\title{
Legal Aspects on the Implementation of Criminal Sanctions in Regional Regulations to Enforce Health Protocols in the Era of Covid-19 Pandemic and Its Problems
}

\author{
Suharyo Suharyo ${ }^{1}$, Yuliyanto Yuliyanto ${ }^{1, *}$, Farikhah Yuni Susilowati ${ }^{1}$, Nevi \\ Anggraeni Raharjo ${ }^{1}$, Siswanto Budi Nugroho ${ }^{1}$ \\ ${ }^{I}$ The Agency of Research and Development of Law and Human Rights of the Ministry of Law and Human Rights \\ of The Republic of Indonesia, Jakarta, Indonesia \\ *Corresponding author. Email: yulikumham.pka@gmail.com
}

\begin{abstract}
This study aims to determine and analyze the approach taken by some Indonesian provincial-level of governments to overcome the Covid-19 pandemic through the formation of regional regulations which incorporate and apply the form of criminal sanctions. This study uses a qualitative-juridical normative approach, which is categorized as library research. In the context of literature research, this study is carried out by collecting data from newspapers, laws, regulations, and various selected secondary materials through which an in-depth and comprehensive analysis is then employed. This study finds out that regional regulations in response to the Covid-19 pandemic, as delegated by higher regulations i.e., the laws, need to be optimized for their effectiveness. This simply means "optimizing the rules while at the same time avoiding the idea of any judicial review attempt from parties who think that there are problems with the regional regulation". This study also points out that after the implementation of the so-called Large-Scale Social Restrictions (PSBB) for more than 6 months, only two provinces have local regulations to prevent and control the spreading of Covid-19, namely NTB and West Sumatra. However, the fact that DKI Jakarta as the center of government and Indonesia's pivot of economy, still relies upon the Governor Regulation Number 88 of 2020 as a source of its local legitimate instrument to prevent, curb and control the pandemic. To complicate the matter, the already mentioned governor regulation also arranges criminal sanctions, especially fines for those who violate the provisions of the regulations. Whereas, legal-procedurally, there should be no criminal sanctions stipulated in any governor regulations. This research limits the scope of the study to the legal aspects on the implementation of criminal sanctions in the regional regulations to overcome the Covid-19 pandemic and its problems. Through this research, the authors want to contribute ideas to the government in demonstrating the presence of the state during the Covid-19 pandemic. Moreover, to prevent legal doubts in society, the regional government should immediately form regional regulation that includes criminal sanctions (both imprisonment and fines) with the adjustment to the aspirations of the community in the regions by respecting local wisdom and human rights.

Keywords: legal aspect, criminal sanction, regional- regulation, covid-19.
\end{abstract}

\section{INTRODUCTION}

The Corona Virus Disease (Covid-19) pandemic in Indonesia that has occurred since March 2020 to date has resulted in a total of 365,240 confirmed positive victims and at least 12,617 deaths in confirmed cases, as per October 19, 2020.[1] The Covid-19 pandemic has crippled if not devastated our nation-wide healthcare system, as well as our economic, cultural and customs. The same problem has also caused a number of legal problems and created a sense of anxiety and fear in almost all levels of society. In the aspect of healthcare and health treatment, we have seen many positive improvements and progress. Unfortunately, in the legal aspect of the Covid-19 pandemic responses, especially in provinces/districts/cities, it is running relatively very slowly. 
As a democratic legal state, the Indonesian government must protect all people, this is shown in the formulation of its policies that uphold the values of justice, human rights and democracy. As a form of efforts to contain the spread of the Covid19 pandemic, the central government has formed a Task Force for handling the Covid-19 pandemic which is stated in Presidential Decree Number 7 of 2020 concerning the Task Force for the Acceleration of Handling Corona Virus Disease (Covid-19) in conjunction with a Presidential Decree Republic of Indonesia Number 7 of 2020 concerning the Amendments to Presidential Decree Number 7 of 2020 concerning the Task Force for the Acceleration of Handling Corona Virus Desease (Covid-19). The task force involved almost all ministries and non-ministerial agencies, and local governments. The Task Force has also carried out a series of policies to tackle the spread of the Covid19 pandemic. In addition, local governments have also anticipated and been directly involved in tackling the spread of the Covid-19 pandemic.

Taking into account the characteristics of the rapid spread of Covid-19 through direct contact between parties suspected of being infected with Covid-19 and other people nearby and in crowds, the government's steps to safeguard public health are carried out by promoting campaigns and enforcement of regulations regarding the implementation of health protocols at least through what is known as $3 \mathrm{M}$ (wearing masks, keeping safe physical distancing and regularly washing hands). The Campaigns and appeals to maintain a safe distance are very effective in preventing human-tohuman transmission of Covid-19, which is now spreading even more massive. Maintaining a safe distance is not meant to limit social interactions, but only to maintain physical distance. Such as online learning, closing or limiting the number of visitors to shopping centers and maximum policies for employees/employees who enter the office. In addition, to carry out general health protocols by wearing personal protective equipment by covering the nose, mouth to chin when interacting and doing outdoor activities.

As time goes by, the spread of Covid-19 is increasingly widespread and the number of patients confirmed positive for Covid-19 is increasing, an instrument established by the central government is implemented to tackle the Covid-19 pandemic, namely Large-Scale Social Restrictions (PSBB). The implementation of the PSBB is carried out by the local government in coordination with the central government, the implementation is carried out for 14 days and can be extended by the local government after conducting a meeting with the Covid-19 Task Force in the area consisting of elements from the local government, the Indonesian National Police, the Indonesian National Army, and the Prosecutor's Office. In promoting the implementation of physical distancing, the government is simultaneously campaigning for the use of masks and washing hands regularly with soap in running water or using hand sanitizers in all aspects of people's lives.

To streamline efforts to build public awareness and their compliance toward the PSBB, applicable laws and regulations are delegated to regional regulations. Unfortunately, what has happened to date is that not all areas affected by the Covid-19 pandemic have local regulations, especially those that regulate large-scale social restrictions, including wearing masks and prohibiting people from crowding around. In tackling the Covid-19 pandemic in the aspect of statutory regulations, regulatory products, which are made/formed in various regions, some are in the form of regional head decrees and very few of them are in the form of regional regulations. In turn, enforcing public discipline towards health protocols is constrained and tends to be less effective. This refers to the fact that regional head decrees do not have the authority to determine sanctions in the form of imprisonment or fines. On the other hand, judging from the legal aspect, the only legal products at the regional level that have the authority to determine criminal sanctions and fines are regional regulations.

In fact, legal products in the response to the Covid-19 pandemic in the regions are a form of the delegation from the legislation above. Meanwhile, to optimize the effectiveness of the implementation of the said regional regulations while at the same time avoiding the idea of a judicial review from parties who feel disadvantaged by the regulation in dispute, regional regulations must be properly formulated. In practice, however, after more than 6 months of the PSBB implementation, only two provinces in Indonesia have regional regulations regarding the prevention and control of the Covid19 pandemic, namely West Nusa Tenggara and West Sumatra. DKI Jakarta as the center of government, economic center, and other centers, still relies upon the Governor of DKI Jakarta Regulation Number 88 of 2020 concerning Amendments to Governor Regulation Number 33 of 2020 concerning the Implementation of LargeScale Social Restrictions in Handling Corona Virus Disease 2019 (Covid- 19) in the Province of the 
Special Capital Region. In addition to regulating the implementation of PSBB, the governor's regulation also regulates health protocols that must be applied to every office, educational place, public transportation, private vehicle, company, and others. What is very odd is that the governor's regulation also regulates the imposition of criminal sanctions, especially penalties in the form of fines, both against citizens and other parties, whereas legal products in the form of governor regulations should not contain criminal sanctions.

The Covid-19 pandemic has brought tremendous suffering to all levels of society in Indonesia. The national health system was hit hard by the "tsunami" both in the care and treatment of patients and hundreds of doctors and medical/health personnel had died within the 7 months of the pandemic. The economic system has also experienced deep collisions throughout Indonesia's history and it has continued to cause a "tsunami" of layoffs, putting more pressure in labor market competition, while on the other hand, national income in the taxation sector has plummeted and the poverty rate has risen quite sharply.

To enforce health protocols in provinces and districts/cities, it is not only based on governor regulations, but in districts/cities there are also those based on mayor/regent regulations by deploying Satpol PP officers, the Transportation Service, the Police, and the TNI. Some of these measures resulted in positive community compliance while not a few violations and noncompliance remain occurred. The assistance of the TNI in handling the prevention and enforcement of the discipline of controlling Covid-19 is in the context of Military Operations Apart from War (OMSP). This is regulated in Law Number 34 of 2004 concerning the TNI, in Article 7 Paragraph (2) Point b Number 9 to assists government tasks in the regions. In implementing the discipline of Covid-19 prevention and control, officers in the field have and continue to display humanist and persuasive attitudes and actions, while providing socialization and paying attention to the violating parties, especially at the age of the violators, general condition (physical), educational level and local wisdom in each area.

In the latest conditions, considering regions that already have regional regulations related to Covid19 countermeasures, on October 19, 2020, the DKI Jakarta Regional House of Representatives passed the draft of regional regulation to handle the Covid19 pandemic. The Regional Government
Regulation on Covid-19 Prevention has previously been proposed by the DKI Jakarta Provincial Government to strengthen the preventive and control functions of the authorities to cut the rate of Covid-19 transmission. The regional regulation regarding the response to the Covid-19 pandemic does not emphasize the imposition of criminal sanctions in the form of imprisonment but tends to impose sanctions in the form of fines.[2] The formulation of regional regulations related to handling the Covid-19 pandemic needs to include criminal sanctions as a tool to "discipline" the public, because there are still many people who violate and do not carry out health protocols, especially in public places. The existence of criminal sanctions is expected to be a deterrent effect for violators, thus forming legal compliance in society.

Departing from the above background, this paper tries to find out the legal aspects of the approach to forming local regulations in tackling the Covid-19 pandemic through the inclusion and application of criminal sanctions and fines to enforce health protocols. The difference between this study and other studies is that this study examines the existing laws and regulations in Indonesia that can be applied in handling a pandemic situation such as what is happening today. Then from these laws and regulations, it is inventoried to be adopted into the formation of Regional Regulations on Handling the Covid-19 Pandemic. From this study, it is hoped that it can be emphasized that when a province, district/city does not have local regulations on handling the Covid-19 pandemic, it will greatly affect law enforcement for health protocol violators.

\section{RESEARCH METHOD}

This study uses a qualitative-juridical normative approach, which is included in library research. A normative juridical approach is an approach that is carried out based on the main legal material by examining theories, concepts, legal principles and laws and regulations related to this research. This approach is also known as the literature approach, namely by studying books and other documents related to this research.

In the context of literature research, it is carried out by collecting data from printed and electronic media, as well as the internet, laws and regulations and various selected secondary materials, which are then analyzed in-depth and comprehensively. Meanwhile, the normative approach is aligned and appropriate for analyzing the products of the 
formation of regional regulations which include the application of criminal sanctions to enforce health protocols in the era of the Covid-19 pandemic and its problems in a democratic constitutional state.

The analysis in this study begins with a process to make an inventory of relevant laws and regulations related to the efforts to tackle communicable disease outbreaks such as the Covid19 that are currently sweeping around the world. In addition, laws and regulations related to disaster management, health quarantine, and the involvement of the TNI, POLRI, and local governments to jointly work together in overcoming the Covid-19 pandemic so that it can be resolved quickly. Then, the results of the inventory are grouped so that they can be used as the material in making local regulations related to the Covid-19 pandemic response.

\section{FINDINGS \& DISCUSSION}

\subsection{Related Legislative Regulations}

The era of globalization in terms of the acceleration and massive mobility of mankind globally, apart from having a positive impact, also has a negative impact on the global health sector as a whole, especially in the spread of global epidemics. The Covid-19 pandemic that is currently hitting the world is one of the impacts of globalization due to the increasing easiness of human movements. Governments around the world are then challenged to be able to balance the dynamic problems that arise due to globalization, in this case the Covid-19 pandemic.

Handling the Covid-19 pandemic requires assertiveness and caution from the government in making its policies, considering that besides, there are health issues, there are also economic issues in it. Indonesia itself has health-related laws and regulations to tackle disease outbreaks such as Covid-19. Law No. 4/1984 concerning Communicable Disease Outbreaks in Article 1 defines an outbreak of a communicable disease as "an outbreak of a communicable disease in a society where the number of sufferers has increased significantly more than normal conditions at certain times and areas and can cause disasters." Looking at this definition, it can be said that the Covid-19 pandemic has arrived at an outbreak of communicable diseases. The government has also declared the Covid-19 pandemic a national disaster through Presidential Decree No. 12 of 2020 concerning the Designation of Non-Natural
Disasters for the Spread of Corona Virus Disease 2019 (Covid-19) as a National Disaster.

Several other related laws and regulations that form the legal basis for handling the Covid-19 pandemic, including:

\section{Law Number 4 of 1984 concerning} Communicable Disease Outbreaks

In addition to providing a mandate for the Minister of Health as the person in charge, this law also regulates criminal sanctions, i.e.:

\section{Article 1}

d. Minister [referred to in this law] is the Minister who is responsible for the health sector.

\section{Article 14}

(1) Anyone who deliberately obstructs the implementation of the epidemic control as regulated in this Law, shall be punished with imprisonment of up to 1 (one) year and/or a maximum fine of Rp. 1,000,000 (one million rupiah).

(2) Whoever due to his/her negligence results in obstruction of the implementation of epidemic control as regulated in this Law, is threatened with imprisonment for a term of 6 (six) months and/or a maximum fine of $\operatorname{Rp~500,000,~-~(five~hundred~thousand~}$ rupiah).

\section{Law Number 24 of 2007 concerning Disaster} Management

After the determination of the Covid-19 pandemic as a national disaster, the National Disaster Management Agency (BNPB) was involved in handling the Covid-19 pandemic. This is as stated in:

\section{Article 5}

The (central) government and local governments are responsible for disaster management

\section{Article 10}

(1) The (central) government as referred to in Article 5 establishes the National Disaster Management Agency.

\section{Law Number 6 of 2018 concerning Health} Quarantine

This law regulates the quarantine of areas caused by disease outbreaks and its consequences for the government and society. The community has an obligation to comply 
with the regional quarantine provisions. The most common provision is the limitation of social interactions among people to reduce the medium for spreading communicable diseases. However, restrictions on the space for the people to move also have consequences for the government to meet the basic needs of society such as health services, access to education, and most importantly the availability of food.

\section{Article 1}

1. Health quarantine is an effort to prevent and block the exit or entry of diseases and/or public health risk factors that have the potential to cause a public health emergency.

11. Large-Scale Social Restrictions are restrictions on certain activities of residents in an area suspected of being infected with a disease and/or contamination in such a way as to prevent the possible spread of disease or contamination.

\section{Article 3}

The implementation of health quarantine aims to:

a. protect the public from disease and/or public health risk factors that have the potential to cause a public health emergency;

b. prevent and ward off disease and/or public health risk factors that have the potential to cause a public health emergency;

c. increasing national resilience in the field of public health; and

d. provide protection and legal certainty for the community and health workers.

\section{Article 4}

The central government and local governments are responsible for protecting public health from diseases and/or public health risk factors that have the potential to cause public health emergencies through the implementation of health quarantine.

4. Law Number 2 of 2002 concerning the Indonesian National Police

In limiting the space for the people to move, the government is assisted by authorized officers, one of which is the Indonesian National Police. One of the duties of the police apparatus is to protect the safety of the people's both mind and body. Therefore, in handling the Covid-19 pandemic, the police can take firm action against the community who obstruct the realization of the safety of the general public.

\section{Article 14}

i. protect the safety of body and soul, property, society and the environment from disturbances of order and/or disaster, including providing assistance and assistance by upholding human rights;

5. Law Number 34 of 2004 concerning the Indonesian National Army

Even though it is not a state of war, the Indonesian National Army (TNI) can be involved in handling the Covid-19 pandemic, especially to optimize the role of the TNI in securing and providing humanitarian assistance to the community.

\section{Article 7}

(2) The main tasks referred to in paragraph (1) are carried out by:

a. non-war military operations, namely to:

b. assist government duties in the regions;

c. assist the Indonesian National Police in the context of security and public order duties as regulated in law;

d. help cope with the consequences of natural disasters, displacement, and provide humanitarian assistance.

6. Law Number 23 of 2014 concerning Regional Government

In accordance with the Communicable Disease Outbreak Law and the Health Quarantine Law, local governments also have their duties and authorities in dealing with the Covid-19 pandemic. The Regional Government Law also states that the health sector is a mandatory government affair relating to basic services for local governments. Therefore, local governments have the authority to issue regulations to deal with the Covid-19 pandemic in their regions.

\section{Article 9}

(1) Governmental affairs consist of absolute governmental affairs, concurrent government affairs, and general government affairs.

(3) Concurrent governmental affairs as referred to in paragraph (1) are governmental affairs that are divided between the central government and provincial and regency/municipal regions.

(4) Concurrent governmental affairs transferred to the regions are the basis for the implementation of regional autonomy. 


\section{Article 11}

(1) Concurrent governmental affairs as meant in Article 9 paragraph (3) which become regional authorities consist of mandatory government affairs and optional government affairs.

(2) Mandatory government affairs as referred to in paragraph (1) consist of government affairs related to basic services and government affairs not related to basic services.

\section{Article 12}

(1) Mandatory government affairs related to basic services as referred to in Article 11 paragraph (2) include:

a. education;

b. health;

c. public works and spatial planning;

d. public housing and residential areas;

e. peace, public order and community protection; and

f. social.

\subsection{The Formation of Regional regulations}

Law Number 12 of 2011 concerning the Formation of Legislation in conjunction with Law Number 15 of 2019 concerning Amendments to Law Number 12 of 2011 concerning the Formation of Laws and Regulations mandating that Indonesia has a hierarchy of laws and regulations, starting from (1) 1945 Constitution, (2) MPR Decrees, (3) Laws or Government Regulations in Lieu of Laws, (4) Government Regulations, (5) Presidential Regulations, (6) Provincial Regulations, to (7) Regency/City Regional Regulations. The order of legislation shows the regulations from the highest to the lowest level. One thing that must be considered is that when discussing the party authorized to form laws and regulations, the word "state or government" is no longer only in the form of the presidency (in this case the cabinet) or government at the national level, but also the legislature, court, to local governments.[3, 59]

Apart from the seven laws and regulations that have been mentioned before, Indonesia is also familiar with other types of regulations, such as regulations from the Parliament [DPR/DPD], Supreme Court, Constitutional Court, Ministers, to Village Head regulations/level. The preparation of statutory regulations must be in accordance with the laws and regulations at its upper level. With regard to the material containing the threat of sanctions for violating regulations, it only exists in the Legislation/Laws and Regional Regulations. Possible sanctions for violators are a maximum fine of 50,000,000 (fifty million rupiah) rupiah or a maximum imprisonment of 6 months. Sanctions that are administrative in nature can also be carried out in the context of enforcement, for example verbal warning, written warning, temporary suspension of activities, permanent cessation of activities, revocation of temporary permits, and revocation of permanent permits.

In accordance with the focus of this paper, according to Law Number 23 of 2014 concerning Regional Government, regional regulations, both provincial and district/city, are prepared in the context of implementing regional autonomy and co-administration, accommodating special conditions that occur in regions, and becoming a further elaboration of higher regulations. The principles for the formation and content of regional regulations are based on the provisions of statutory regulations and legal principles that develop in the community. In the formulation process, the role and participation of the community are very important. The quality of the draft of regional regulation that is later passed into a regional regulation is largely determined by how the draft is being prepared. [4] The thing that needs to be the main concern is public participation, not only during socialization or public testing, but also further, namely public involvement in the design stage from the very beginning to the evaluation stage. Public participation can be done through the people's representative institutions (DPRD) or directly through the public hearing stages. This public participation can be done from the planning, socialization and implementation stages, even to the evaluation one. This becomes important in order to formulate regional regulations that are efficient and effective or right on target.

According to Soerjono Soekanto, the law becomes effective when it meets five conditions, namely, first, the legal factor, where it is stated that the law will be effective when it contains elements of justice, legal certainty, and benefits. The law that is made must be sure that it will bring justice and benefit to anyone without exception. Second, law enforcement factors. Law will become 
effective when law enforcement institutions and law enforcement officers are able to carry out and fulfill their duties and functions properly, there is no such thing as "selective cutting" in law enforcement. Third, the law enforcement facilities. The law will be effective when it is supported by adequate law enforcement facilities. Fourth, the community factor. The law will be effective when there are a willingness and legal awareness from the community to comply with existing regulations. Thus, participation in the formulation and implementation of regulations is the key. The community must be willing and aware that the formulated regulations are for the common good. This can be achieved when the community is involved in every stage of the drafting. Fifth, cultural factors. The law will be effective when it is in line with the prevailing values and norms and when it grows and develops in everyday people's life.[5]

In order to optimize the response to curb the Covid-19 pandemic, especially in the aspect of disciplining members of the wider community, the application of criminal sanctions and/or fines as ultimum remidium is a very possible option. This is done because the socialization of the dangers of Covid-19 has been and continues to be carried out massively in various aspects of the community's life. The formation of special regional regulations on handling the Covid 19 pandemic which is still very minimal amid the continuous spreading of the epidemic throughout Indonesia. This has been the biggest obstacle in realizing public discipline to comply with and obey health protocols as the main step in controlling the Covid-19 pandemic.

The formation of laws will follow the socio-political structure of each country. For a country that adheres to an authoritarian political configuration, the formation of the law will also show an authoritarian character. When the process of forming the law (legislation) is placed in the context of the socio-political structure of a democratic country, there will inevitably be compromises from conflicts of values and different interests in society.[6] Local government can be an agent of change in shaping health policy, thus not only acting as a mere implementer of central policies. [7, 180]
There is always an opportunity to form local regulations where the drafting of regional regulation falls outside the scheduled Perda formation program. DPRD or regional heads may in certain circumstances propose the formation of a regional regulation for the following reasons:

a. coping with extraordinary circumstances, situations of conflict or natural disasters.

b. following up cooperation with other parties.

c. overcoming certain other conditions that ensure the urgency of a draft of regional regulation that can be jointly approved by the DPRD apparatus that specifically handles the field of regional regulation formation and the unit that handles the legal sector in the regional government.

d. orders from the higher level statutory provisions after the regional regulation formation program is enacted.[8]

In principle, the formation of a legal product or statutory regulation must reflect the ideology of the nation, its soul and personality, its outlook on life and be based on strong fundamental principles of the state for realizing national goals (Pancasila).[9] When a legal product is in accordance with the state foundation which is inspired by the community, it must be more acceptable to the community. Thus, it does not require more effort to internalize the law or products of the established legislation.

The process of law formation (legislation) is a relatively very important process as it is relatively paramount to see the implementation and enforcement process of the law itself. The processes that occur in the formation of the law, however, will influence the process of implementing and enforcing the law. Mistakes in the process of law formation can have fatal consequences, because the erroneous process of forming a law can give birth to legal products that are criminogenic in social interactions.[10] As previously emphasized by the author, the process of law formation is closely related to community participation. It is hoped that the law resulting from deliberation with the community will be easier to apply, because it is in accordance with the wishes or at least in accordance with the agreement between the various elements of 
society who are affected. Once again, this will further minimize the effort required in implementing law enforcement.

It is hoped that the impact of law enforcement efforts on perpetrators is expected to have a deterrent effect so that they do not repeat similar actions and for the community, it is expected to be part of legal understanding and education, as well as to build a level of public confidence that every existing provision must be obeyed.[11] The law enforcement process is a stage that determines whether the legal product produced is acceptable or not as a reference for life in people's daily lives. Various approaches need to be made so that the community voluntarily and consciously accepts and puts into practice the legislation that has been produced. The feeling of "forced" from the community should fade over time and be replaced by a feeling of conscious acceptance that the regulations formed are really needed in order to overcome the existing problems. Supposedly, public compliance with existing laws no longer depends on the threat of sanctions or punishment, but based on the legal awareness of the community itself. However, when a new legal product is issued, the existence of the threat of criminal sanctions (both imprisonment and fines, or even social work) is very helpful in enforcing these regulations.

\subsection{Criminal Sanctions}

\section{The Formation (Article 238 of Law 23/2014 on Products of Regional Regulations)}

In fact, the development of criminal law is increasingly being used and relied on in order to regulate and order society through statutory regulations. The dynamics of law can be seen from the policy on the use of criminal sanctions through the inclusion of a chapter on the provisions of criminal sanctions at the end of most products of legislation in Indonesia. The inclusion of a chapter on the provisions of criminal sanctions is not only visible in the products of the central legislation in the form of laws but can also be seen in the products of local legislation in the form of regional regulations.[12]

In the era of regional autonomy, the formation of regional regulations falls under the authority of the regional government (Governor, Mayor and Regent) and the People's Representative Council. For its formation itself, there must be a mutual agreement between the regional head and the DPRD. Judging from the main sanctions imposed in the form of the threat of imprisonment and fines, which reflect the presence of the state in creating balance and protecting society. In accordance with Article 15 of Law Number 12 of 2011 concerning the Formation of Legislation, the criminal provisions in regional regulations have a maximum imprisonment of 6 months and a maximum fine of five million rupiah. The existence of a content of sanctions in a legal product in the form of regional regulations is in fact an instrument to create a deterrent effect because the existence of regulations cannot be separated from the sanctions, the absence of sanctions will make it difficult to implement a regulation so that without sanctions it will be difficult to achieve the goal of establishing a regional regulation.

It cannot be denied that a product of regional regulations which includes criminal sanctions, in the context of a democratic rule of law, is a kind of warning or deterrent factor so that the public can better know, understand and observe that even in violating a regional regulation he/she can be subjected to sanctions in the form of imprisonment and/or fines. In the development of the handling of the Covid19 pandemic in various places with a variety of regulatory products made in the regions specifically to enforce the discipline of health protocols, violators are given optional sanctions, either in the form of fines or limited social work.

Imposing criminal sanctions is one of the efforts to deal with the Covid-19 pandemic as stipulated in a regional regulation. The use of this sanction is considered to be stronger and more precise in its implementation, for example in DKI Jakarta, where prior to the formation of the local regulation on handling the Covid-19 pandemic which was recently passed by its representative council, it relied on the Governor's Decree and the Governor's Regulation as a legal legitimation in handling the spread of Covid-19 pandemic in DKI Jakarta. Criminal sanctions for violators of health protocols are needed so that all people understand and are educated in the context of 
preventing and eradicating a pandemic. Not a few people underestimate the importance of the application of health protocols to curb the spread of the pandemic without thinking about the serious impact caused by their actions and the public anxiety they have caused. This is in accordance with Jan Remmelink's opinion about why the state acts when a crime occurs and why the state acts by imposing suffering sanctions. This is intended as an appropriate means because it encourages the state to act fairly and avoid injustice. Criminal punishment therefore functions as a social and psychological threat mechanism.[13]

The extraordinary circumstances in the Covid-19 cases in DKI Jakarta forced the Regional Government to draft a specific Raperda. The Raperda, which has been approved by the DKI Jakarta's Regional People's Representative Assembly as a Regional Regulation on October $19^{\text {th }}, 2020$, contains 11 chapters and 35 articles which regulate the provisions, responsibilities, authority, and sanctions during the handling of the Covid-19 pandemic in DKI Jakarta. In this regional regulation, the existence of criminal sanctions in the form of imprisonment is removed and sanctions in the form of fines are the only substitutions. Administrative fines can be imposed on individuals who deliberately refuse the Reverse Transcriptase Polymerase Chain Reaction test or Molecular Rapid Test as stated in article 29, and individuals who deliberately carry a corpse that is probable or confirmed positive for Covid-19 without permission from a health worker as contained in article 31 , as well as individual patients who leave the isolation facility without the permission of the officer as stated in article 32.[14]

\section{The Application}

In the application of criminal sanctions as stipulated in regional regulations, they must be implemented proportionally and based on respect for human rights. The criminal sanction is essentially a loss in the form of suffering deliberately given by the state to individuals who violate the law. However, punishment is also a moral education for the perpetrator who has committed a crime (which is minor) with the intention that he/she will no longer repeat his/her actions in the future.[15]
In implementing and enforcing regional regulations, local governments make operational the use of the Civil Service Police (Polisi Pamong Praja) units. In a condition where the Civil Service Police is deemed incapable of enforcing a regional regulation, a regional head can ask for assistance from the Police, even the TNI, which becomes a common thing, for example in policing operations, evictions and land/building acquisition. So, it is very natural that handling Covid 19 as a non-natural national disaster must involve the Civil Service Police, Police, and TNI to discipline the public regarding health protocols. However, in practice, law enforcement must also prioritize universal human rights values in its enforcement. Both the Chief of the Indonesian National Police and the Commander of the Indonesian National Armed Forces have given directions to his staff to carry out procedures for prosecuting health protocol violators as an element of assistance related to humanely handling the Covid-19 pandemic.

Law enforcement with regional regulations has actually been carried out in several regions to create public order, such as in the Regional Regulation made by the Badung Regency Government, namely the Badung Regency Regional Regulation Number 7 of 2016 concerning Public Order and Peace of the Community. The regulation oversees 3 (three) prohibited points. First, it is addressed to beggars and homeless people, which contains the prohibition against begging to other people and/or other disturbing activities on the streets and traffic lights along with the prohibition to live in and/or do activities that are not intended for public facilities and/or social facilities. Second, the prohibition is aimed at the superiors of beggars which contains prohibitions on coordinating beggars, buskers, hawkers, car sweaters on the road and/or public places, and prohibitions on exploiting children and/or toddlers to beg. Third, it is aimed at the public not to give any amount of money and/or goods to beggars and vagabonds who roam the streets and/or in public places.[16] 


\subsection{The Problems}

\section{Public distrust of the Covid-19 pandemic}

During the Covid-19 pandemic which has disrupted various systems in Indonesia, such as the economy, health, and others, there are still many Indonesians who doubt the existence of Covid-19. According to the Chairperson of the Covid-19 Task - Doni Monardo, it is revealed that based on an internal survey, there is still 17 percent of the public who do not believe in and considered it impossible and very unlikely [for them] to be exposed by Covid-19.[17]

The same thing was also mentioned by the Central Statistics Agency (BPS) which stated that as many as 17 percent of the public believed that it was impossible [for them] to contract Covid-19. This is based on the results of a survey on community behavior during the pandemic which was conducted by BPS from $7^{\text {th }}$ to $14^{\text {th }}$ September 2020. In the survey, it was revealed that as many as 12.5 percent of respondents said that it was impossible [for them] to contract Covid-19. Meanwhile, another 4.5 percent actually said that it was very unlikely for them to be infected with Covid-19.[18]

This sense of public distrust greatly affects the level of compliance and public awareness in implementing health protocols, and it can be assumed that those who doubt or do not believe in Covid-19 are definitely not correctly implementing health protocols. Therefore, local governments must be able to enforce health protocols by issuing local regulations which include imposing sanctions on health protocol violators.

\section{Many Indonesian's Regional Government do not yet have local regulations to deal with the Covid-19 Pandemic}

To date, as per $20^{\text {th }}$ October 2020 - based on the author's notes, only three provinciallevel of regional governments in Indonesia have already had local regulations regarding the response to the Covid-19 pandemic, namely West Sumatra, West Nusa Tenggara, and DKI Jakarta. The majority of others do not yet have specific regional regulations regarding the handling of the Covid-19 pandemic. Local governments, both provincial and district/city level, rely heavily on the decree of the regional head for the enforcement of health protocols in handling Covid-19. The legal product in the form of a Regional Head Decree is seen to be deemed ineffective for enforcing health protocols in their respective regions because it has no authority to stipulate determine and instrumentalize sanctions, both criminal sanctions and fines. As a result, many people still ignore health protocols for various reasons and excuses.

On the other hand, the application of sanctions in the form of fines might become difficult for people who are materially incapacitated. For that, however, there are options to replace fines with social work (such as. cleaning garbage or drains, etc.). In the meantime, violations of health protocols committed by companies, offices, transportation services, and others, need to be firmly enforced, so that the mandate of the existing regional regulations regarding the prevention of the Covid-19 pandemic is not in vain.

\section{Government policy disharmony}

Some government policies taken during the Covid-19 pandemic were, in fact, inconsistent and even conflicting between one ministry to another, or between the central government to regional governments. For example, the policies of the Ministry of Education and Culture which clearly and firmly prohibit direct or face-to-face learning and teaching activities and the policies of Ministries/Institutions and BUMNs to carry out Work from Home (WFH) which aims to prevent the spread of Covid-19 transmission. Ironically, the Ministry of Religion has made a series of policy that contradicts other ministries/agencies by issuing policies to open and restore daily routine activities in Islamic boarding schools. This is of course a very unfortunate event considering that life in Islamic boarding schools is based on kinship with intensive social interaction that makes it very difficult and almost impossible to enforce strict health protocols in the boarding schools. As a result, new clusters of the spread of covid-19 have emerged and have threatened the safety and health of the residents of the boarding schools themselves. 


\section{The ineffectiveness of the Task Force for handling the Covid-19 pandemic at the regional level}

The enforcement of health protocols carried out by the Covid-19 pandemic response task force at the regional level seems only temporary, and does not appear to be continuous. Meanwhile, the involvement of all elements of society to comply with and adhere to health protocols has not fully shown optimal results. Culture and habits in public spaces such as wearing masks, maintaining physical distance, and washing hands frequently still face a number of obstacles. This is exacerbated by a large number of TV shows in the form of entertainment and soap operas that have not fully shown support for the government's campaign for the correct implementation of health protocol. In fact, TV shows are one of the most popular socialization media for the prevention of Covid-19 which has a high potential for success in the implementation of socialization and internalization in efforts to prevent Covid19 transmission. Indonesian people who are oriented towards certain figures (actors/ actresses of Indonesian's popular electronic cinemas or "soap operas" as the example) will of course tend to follow what these figures do. A step that seems mutually beneficial, on the one hand, soap opera production continues, while the socialization of preventing the spread of Covid-19 also continues to go on.

\section{CONCLUSION}

The presence of the "State" and "its governmental apparatus" is needed to tackle the Covid-19 pandemic in Indonesia. In addition, in the era of decentralization, the formation of regional regulations to respond the Covid-19 pandemic which includes criminal sanctions and fines is an urgent and emergency step. Therefore, Regional Governments that do not yet have Regional Regulations on Handling the Covid-19 Pandemic must immediately issue a Regional Regulation containing criminal sanctions (both imprisonment and fines, or even social work) for violators of health protocols. The Regional Regulation must be adjusted to the aspirations of the local community by respecting and respecting local wisdom and human rights. Thus, with the existence of the Regional Regulation on Handling the Covid-19 Pandemic, Regional Government officials who have the duties and functions of law enforcement, namely "Satuan Polisi Pamong Praja" can firmly take action against any violators of health protocols.

Moreover, the Covid-19 handling task force at the regional level must provide examples for community members to comply with health protocols, considering that the task force is a humanitarian officer and one of the front lines in the response to the Covid-19 pandemic. Additionally, socialization and education to the wider community about the dangers of the Covid19 pandemic must not be loose. For parties or individuals who oppose, ignore, and violate health protocols, the choice of law in the form of criminal sanctions and/or fines or social work must be applied according to the situation and conditions in the community. In the end, the involvement of the community and religious leaders, associations, community organizations, education and community members who have recovered from the Covid-19 infection is needed to make all levels of society aware of the dangers of Covid-19, and this must be done massively.

\section{REFERENCES}

[1] "Satuan Tugas Penanganan Covid-19," 2020. [Online]. Available: https://covid19.go.id/.

[2] "Sah, DKI Jakarta Miliki Perda Penanggulangan Covid-19," DPRD Provinsi DKI Jakarta, 2020. [Online]. Available: http://dprd-

dkijakartaprov.go.id/sah-dki-jakarta-milikiperda-penanggulangan-covid-19/.

[3] Simon Butt and Nicholas Parsons, "Judicial Review and the Supreme Court in Indonesia: A New Space for Law?," Southeast Asia Progr. Publ. Cornell Univ., vol. No. 97, p. 59, 2014.

[4] Suharyo, "Pembentukan Peraturan Daerah dan Penerapan Sanksi Pidana serta Problematikanya," Rechtsvinding, vol. 4, p. 433, 2015.

[5] S. Soekanto, Faktor-Faktor yang Mempengaruhi Penegakan Hukum. Jakarta: Raja Gravindo Persada, 2007.

[6] A. Ibrahim, Legislasi dan Demokrasi Interaksi dan Konfigurasi Politik Hukum dalam Pembentukan Hukum di Daerah. Malang: Intrans Publishing, 2008.

[7] D. Fossati, "From Periphery to Centre: Local Government and the Emergence of Universal Healthcare in Indonesia," Contemp. Southeast Asia, vol. 39, p. 180, 2017. 
[8] E. Nurbaningsih, Problematika Pembentukan Peraturan Daerah Aktualisasi Wewenang Mengatur dalam Era Otonomi Luas. Depok: Rajawali Press, 2019.

[9] K. F. Sulaiman, Teori Peraturan Perundang-Undangan dan Aspek Pengujiannya. Yogyakarta: Thafa Media, 2017.

[10] S. Rahardjo, Sisi-Sisi Lain Hukum di Indonesia. Jakarta: Buku Kompas, 2003.

[11] W. Pramono, Pemberantasan Korupsi dan Pidana Lainnya: Sebuah Perspektif Jaksa dan Guru Besar. Jakarta: Buku Kompas, 2016.

[12] T. Prasetyo, Kriminalisasi dalam Hukum Pidana. Bandung: Nusa Media, 2010.

[13] J. Remmelink, Hukum Pidana - Komentar Atas Pasal-Pasal Terpenting dari KUHP Belanda dan Pidananya dalam KUHP Indonesia. Jakarta: PT. Gramedia Pustaka Utama, 2003.

[14] R. N. Velarosdela, “, Ini 6 Aturan Baru dalam Perda Penanggulangan Covid-19, Siap-siap Denda Jutaan Rupiah jika Melanggar," Kompas.com. .

[15] E. O. S. Hiariej, Prinsip-Prinsip Hukum Pidana Edisi Revisi. Yogyakarta: Cahaya Atma Pustaka, 2014.

[16] N. G. A. D. S. Putu Putra Baruna Karmanta, "Penegakan Hukum Terhadap Gepeng Di Kawasan Pariwisata Kuta Kabupaten Badung Berdasarkan Perda Nomor 7 Tahun 2016," Ilmu Huk., vol. 06, pp. 5-6, 2018.

[17] L. T. Tambun, "17\% Masyarakat Tidak Percaya Covid-19," BeritaSatu.com, 2020. [Online]. Available: https://www.beritasatu.com/yudodahono/nasional/686555/17-masyarakattidak-percaya-covid19.

[18] E. Nordiansyah, "Survei BPS: 17\% Masyarakat Percaya Tidak Mungkin Tertular Covid-19," medcom.id, 2020. [Online]. Available: https://www.medcom.id/ekonomi/bisnis/Ob zZGvYb-survei-bps-17-masyarakatpercaya-tidak-mungkin-tertular-covid-19. 